\title{
What is the role of music in the intensive care unit?
}

\author{
Phumpattra Chariyawong MD, Samuel Copeland MD, Zachary Mulkey MD
}

Music has been integral to human development and advancement with the power to convey powerful emotions. It is not surprising that music is played all across the globe and that it has been found advantageous in the field of medicine. Music has been shown to help surgeons perform operations faster and to help in neurologic recovery following traumatic brain insults. ${ }^{1,2}$ Music therapy is also unique in that it is very safe and the cost of implementation is low. Most hospitals have an easy listening TV channel that couples peaceful music and imagery.

The intensive care unit is a unique patient care experience. It is an extremely busy and loud place with frequent alarms and flashing lights where sleep often eludes patients. Unfortunately, these disturbances in sleep are dramatic and can lead to multiple co-morbidities, including ICU delirium which is associated with a 3.2 fold increase in six month mortality. ${ }^{3,4}$ We wondered if there is evidence to support a beneficial effect of music in the intensive care setting. Specifically, we wondered whether music therapy could decrease sedation requirements, improve patients' anxiety ratings, and improve hemodynamic parameters. Most of the literature discusses patients who are undergoing mechanical ventilation. These patients are susceptible to multiple stressful factors which can cause anxiety and in turn increase oxygen consumption. ${ }^{5}$

The first question was whether music therapy improves a patient's sleep quality in the ICU over standard care without the addition of music. Su developed a randomized controlled trial in which patients were randomized to noncommercial music for 45 minutes at nocturnal sleep time or usual care with no music. The music consisted of sedating piano pieces composed by the authors of the study. Polysomnography was

Corresponding author: Samuel Copeland Contact

Information: Samuel.copeland@ttuhsc.edu

DOI: $10.12746 /$ swrecc2016.0416.218 recorded for the first two hours of sleep. Results showed that stage N2 sleep was shorter by 5.2 minutes and stage N3 sleep was longer by 6.5 minutes in the first two hours. Patients in the music group had significantly lower heart rates and reported improved sleep quality over the control group. ${ }^{6}$

The second question was whether music is actually beneficial or is it simply the reduction in background ICU noise that offers benefits. In the largest music focused clinical trial to date, Chlan found that there are multiple benefits to music therapy. Experimental patients in the MICU were recruited and divided into three groups of either patient-driven music (PDM), noise-cancelling headphones $(\mathrm{NCH})$, or control. Patients in the experimental group had an anxiety score that was 19.5 points lower than the control group. In addition, patients in the experimental group also used fewer sedatives, both in intensity and frequency, than control patients. Both findings were statistically significant. Their conclusion was that in patients receiving ventilator support for respiratory failure, PDM and $\mathrm{NCH}$ resulted in greater reduction in anxiety compared with usual care. Interestingly, when PDM is compared to $\mathrm{NCH}$, there was no statistically significant difference in the reduction in anxiety or sedation intensity in PDM compared with $\mathrm{NCH}^{7}{ }^{7}$ This study demonstrates that some type of therapy is preferable to none, but it does not answer the question of whether music therapy is driving the lower anxiety scores.

Another study by Chlan evaluated the effectiveness of music therapy on relaxation and anxiety in mechanically ventilated patients. Patients experienced significantly less anxiety assessed by pretest-posttest state anxiety scores. Physiologic parameters were also measured. The heart rates and respiratory rates decreased significantly over time in patients in the study group compared to the control group, suggesting relaxation and less stress-arousal. ${ }^{8}$ Positive effects of music on anxiety levels based on patient perception have been supported by several studies. Wong conducted a study of music therapy on anxiety in twenty 
ventilator-dependent Chinese patients. The results suggested that music therapy was more effective in decreasing state anxiety than an uninterrupted rest period. Physiologic measures of blood pressure and respiratory rate were significantly lower by the end of the 30 minutes of music. ${ }^{9}$ Almerud evaluated qualitative and quantitative measures after mechanically ventilated patients listened to classical music for 30 minutes. Systolic and diastolic blood pressures significantly fell during the music therapy session and rose after the end of the session. ${ }^{10}$ One randomized controlled trial of twenty subjects did not support the conclusion that music influences physiologic parameters. This study indicated that listening to music leads to higher sedation scores but no significant decrease in blood pressure and heart rate. ${ }^{11}$ However, this study collected data from sedated mechanically ventilated patients whose blood pressures and heart rates might be lower than patients' baseline secondary to sedative drugs. Music may not have additional effects when added to pharmacological sedation. In aggregate these studies indicate that music therapy might improve anxiety using both psychological and physiological criteria.

Not only patients in medical intensive care units, but patients in cardiovascular intensive care units seem to benefit from music therapy. Two studies have reported good outcome of music therapy on cardiovascular disease patients. White used a three group repeated measures experimental design in forty-five patients with acute myocardial infarction. Patients were divided into three groups: 1. music in quiet, restful environment (experimental group), 2. quiet, restful environment without music (attention group), and 3. treatment as usual (control group). State anxiety was reduced significantly immediately during the intervention and for one hour after the intervention in the experimental group only. Heart rate, respiratory rate and myocardial oxygen demand were significantly decreased immediately during the intervention and for one hour after in the experimental group compared to the control group but did not differ significantly differ from the attention group. ${ }^{12}$ Barnason studied effects of music on anxiety in coronary artery bypass graft patients. Spielberger's state-trait anxiety inventory, patient's verbal ratings of both mood and anxiety by numeric rating scale, and physiologic parameters were measured. This study found significant improvement in mood but not in anxiety scores in these subjects. Heart rate and systolic and diastolic blood pressures were significantly decreased by the intervention, indicating generalized physiologic relaxation. ${ }^{13}$ These two studies indicate that music is not harmful to patients and may help improve mood, anxiety, and physiologic responses to stress. However, Elliot did not find any relation between music therapy and anxiety reduction in a randomized controlled trial. Both psychologic and physiologic variables were measured but there was no significant reduction in anxiety in patients exposed to music. The author claimed that these results may be explained by a type II error. ${ }^{14}$

Most of the studies have focused on noninvasive measures, such as subjective state anxiety and physiologic parameters, such as blood pressure, respiratory rate, and heart rate. The human body also responds to stress with hormone release. Cortisol, corticotrophin, epinephrine, and norepinephrine levels increase when patients are under stress. Chlan studied the influence of music on these biomarkers using a 2-group experimental design with repeated measures study of 10 patients. The levels of cortisol, corticotrophin, epinephrine and norepinephrine were measured four times during 60 minutes. However, there were no significant changes in these four biomarkers in patients who listened to music and in patients who rested quietly. ${ }^{15}$ Chlan also measured 24 hour urinary free cortisol levels as a stress biomarker in 70 patients; music intervention did not significantly reduce urinary free cortisol levels. ${ }^{16}$

Our review of the literature indicates that there were important differences among trials studying whether music therapy has physiologic benefits. Chan took note of these differing results and proposed that there may be demographic differences that would make patients more or less likely to respond to music therapy. In his randomized trial, he studied Chinese patients 
admitted to an ICU and was able to categorize patients into two distinct clusters. He found that older, less educated females had a greater response to music therapy played over a 30 minute period with reductions in pulse, blood pressure, and respiratory rate. Those who were less likely to respond were younger, male, and more educated, with only a significant reduction in systolic blood pressure noted with music therapy. ${ }^{17}$ This study suggests that certain population subgroups may be more influenced by music therapy. The types of music that were offered in the study were limited to Chinese classical music, religious Tibetan music, Western classical, or Jazz. It is universally understood that there are different preferences in music. While one person may enjoy classical music, another person may find the rhythms of heavy metal to be soothing; this leads us to the questions of whether patients' personal preferences affect their responses. The general recommendation for music used to relax patients is soothing music with a sustained melodic quality and a general absence of strong rhythms, percussions, and lyrics.

To answer whether a specific type of music should be used, Chi performed a literature review. Her analysis concluded that overall results indicated music selected on the basis of research yielded better results that music selected simply on basis of individual preference. The argument was that music that was selected by an individual could cause stimulation rather than relaxation. Specifically, she found that music specially designed to enhance relaxation was effective in treating tension and negative moods. This concept was at least partly refuted by noting that repetitive exposures to music increased the listener's comfort level. This finding led them to ask whether patient preference should play a role in music selection. Their review suggested that personal preference, familiarity, cultural background, and past experiences should not be ignored. They suggest that while patient preference should be considered, the first consideration must always be grounded in research. Their conclusion was that music chosen by research generally produces more relaxation, reduces pain or anxiety, and prevents stress induced changes in psychological responses. Patients should be given options for listening, but each option should be research driven so that it has the highest chance of achieving the desired outcome. $^{18}$

Overall, the evidence suggests that music therapy should routinely be prescribed for patients in the intensive care unit. Nurses have a key role in music implementation. We suggest that music therapy should be triggered by a nursing assessment of either elevated CAM ICU scores, hemodynamic parameters which suggest acute agitation, or patient reported anxiety. Demographics should be considered when implementing music therapy, but demographics should not prevent offering therapy. The type of music should be geared towards relaxation, and patients should be offered music often. Multiple relaxing selections should be offered so that patients can choose which one they feel is most suitable for relaxation and better physiologic outcomes.

Key words-ICU, music therapy, agitation, anxiety 


\section{Table 1. Summary of Reviewed Studies}

\begin{tabular}{|c|c|c|c|c|}
\hline Author & $\mathrm{Su}^{6}$ & Chlan $^{7}$ & Chlan $^{8}$ & Wong $^{9}$ \\
\hline Type of Trial & RCT & RCT & $\begin{array}{l}2 \text { group, pretest-posttest } \\
\text { experimental design }\end{array}$ & $\begin{array}{l}\text { Crossover repeated measures } \\
\text { design with random } \\
\text { assignment }\end{array}$ \\
\hline Number of patients & 28 & 373 & 54 & 20 \\
\hline Main Outcome & $\begin{array}{l}\text { Hemodynamics, } \\
\text { polysomnography, vSH sleep } \\
\text { scale }\end{array}$ & Anxiety and sedative use & $\begin{array}{l}\text { Anxiety, heart rate and } \\
\text { respiratory rate }\end{array}$ & $\begin{array}{l}\text { Mean blood pressure, } \\
\text { respiratory rate, Spielberger } \\
\text { State Trait Anxiety Inventory }\end{array}$ \\
\hline Results & $\begin{array}{l}\text { Music group had shorter } \\
\text { stage N2 sleep and longer } \\
\text { stage N3 sleep, lower heart } \\
\text { rates, and reported better } \\
\text { sleep quality }\end{array}$ & $\begin{array}{l}\text { Experimental groups } \\
\text { experienced decreased } \\
\text { anxiety scores and sedative } \\
\text { exposure compared to the } \\
\text { control group. }\end{array}$ & $\begin{array}{l}\text { Music therapy group } \\
\text { significantly less anxiety and } \\
\text { decrease heart rate and } \\
\text { respiratory rate compared to } \\
\text { control group }\end{array}$ & $\begin{array}{l}\text { Music therapy was more } \\
\text { effective in decreasing } \\
\text { anxiety and decreased blood } \\
\text { pressure and respiratory rate } \\
\text { at the end of the intervention }\end{array}$ \\
\hline Conclusion & $\begin{array}{l}\text { Soothing music can be used } \\
\text { in the ICU to improve } \\
\text { patients sleep }\end{array}$ & $\begin{array}{l}\text { Patient directed music } \\
\text { resulted in greater reduction } \\
\text { in anxiety compared with } \\
\text { usual care but not noise } \\
\text { cancelling headphones }\end{array}$ & $\begin{array}{l}\text { A single music therapy } \\
\text { session found to be effective } \\
\text { for decreasing anxiety and } \\
\text { promoting relaxation }\end{array}$ & $\begin{array}{l}\text { Music therapy is an effective } \\
\text { intervention in decreasing } \\
\text { anxiety in ventilator } \\
\text { dependent patients }\end{array}$ \\
\hline Author & Almerud $^{10}$ & Dijkstra $^{11}$ & White $^{12}$ & Barnason $^{13}$ \\
\hline Type of Trial & $\begin{array}{l}\text { Quantitative and qualitative } \\
\text { methods }\end{array}$ & RCT with repeated measures & $\begin{array}{l}3 \text { group repeated measures } \\
\text { experimental design }\end{array}$ & $\begin{array}{l}\text { Prospective, repeated } \\
\text { measures, quasi- } \\
\text { experimental, random } \\
\text { assignment }\end{array}$ \\
\hline Number of patients & 20 & 20 & 45 & 96 \\
\hline Main Outcome & $\begin{array}{l}\text { Systolic, diastolic blood } \\
\text { pressure and heart rate }\end{array}$ & $\begin{array}{l}\text { Systolic, diastolic, mean } \\
\text { arterial blood pressure, heart } \\
\text { rate, respiratory rate }\end{array}$ & $\begin{array}{l}\text { Anxiety level, heart rate, } \\
\text { respiratory rate and } \\
\text { myocardial oxygen demand }\end{array}$ & $\begin{array}{l}\text { Anxiety, mood, blood } \\
\text { pressure and heart rate }\end{array}$ \\
\hline Results & $\begin{array}{l}\text { Significant fall in systolic and } \\
\text { diastolic blood pressure } \\
\text { during music therapy session } \\
\text { and a corresponding rise after } \\
\text { cessation of treatment }\end{array}$ & $\begin{array}{l}\text { Higher sedation scores in } \\
\text { experimental group, no } \\
\text { significant differences in } \\
\text { physiologic parameters }\end{array}$ & $\begin{array}{l}\text { Significant reduction in heart } \\
\text { rate, respiratory rate, } \\
\text { myocardial oxygen demand } \\
\text { in experimental compared to } \\
\text { control group but not in } \\
\text { attention group. Anxiety } \\
\text { reduced in experimental } \\
\text { group only, }\end{array}$ & $\begin{array}{l}\text { Significant mood } \\
\text { improvement but no } \\
\text { significant differences of } \\
\text { anxiety ratings, significant } \\
\text { effects over time on heart } \\
\text { rate, systolic and diastolic } \\
\text { blood pressure }\end{array}$ \\
\hline Conclusion & $\begin{array}{l}\text { Intensive care nursing staff } \\
\text { can beneficially apply music } \\
\text { therapy as a non- } \\
\text { pharmacological intervention }\end{array}$ & $\begin{array}{l}\text { Music associated with higher } \\
\text { level of sedation in sedated, } \\
\text { mechanically ventilated ICU } \\
\text { patients }\end{array}$ & $\begin{array}{l}\text { Patients recovering from } \\
\text { acute myocardial infarction } \\
\text { may benefit from music } \\
\text { therapy in quiet, restful } \\
\text { environment }\end{array}$ & $\begin{array}{l}\text { The overall response by all } \\
\text { intervention groups } \\
\text { demonstrated relaxation } \\
\text { response. Reduced anxiety } \\
\text { and improved mood within } \\
\text { all three groups. }\end{array}$ \\
\hline Author & Elliott $^{14}$ & Chlan $^{15}$ & Chlan $^{16}$ & Chan $^{17}$ \\
\hline Type of Trial & RCT & RCT & $\begin{array}{l}2 \text { group experimental design } \\
\text { with repeated measures }\end{array}$ & Repeated measures design \\
\hline Number of patients & 56 & 70 & 10 & 101 \\
\hline Main Outcome & $\begin{array}{l}\text { Psychologic and physiologic } \\
\text { variables }\end{array}$ & Urinary free cortisol & $\begin{array}{l}\text { Levels of cortisol, } \\
\text { corticotrophin, epinephrine } \\
\text { and norepinephrine }\end{array}$ & $\begin{array}{l}\text { Demographic characteristics, } \\
\text { physiologic parameters }\end{array}$ \\
\hline Results & $\begin{array}{l}\text { No significant reduction in } \\
\text { anxiety was achieved for } \\
\text { patients using music or } \\
\text { muscle relaxation } \\
\text { interventions. }\end{array}$ & $\begin{array}{l}\text { No significant differences } \\
\text { among groups in urinary free } \\
\text { cortisol over the course of } \\
\text { ventilator support }\end{array}$ & $\begin{array}{l}\text { Levels of } 4 \text { biomarkers did } \\
\text { not differ significantly } \\
\text { between patients who listened } \\
\text { to music and patients who } \\
\text { rested quietly }\end{array}$ & $\begin{array}{l}\text { Cluster analysis yielded } 2 \\
\text { clusters. Cluster } 1 \text { was } \\
\text { younger educated males and } \\
\text { had less effect from music } \\
\text { therapy. Cluster } 2 \text { was older } \\
\text { uneducated females and had } \\
\text { more effect from music } \\
\text { therapy }\end{array}$ \\
\hline Conclusion & $\begin{array}{l}\text { These results differ from } \\
\text { those of similar studies but } \\
\text { may be related to the high } \\
\text { probability of a type II error. }\end{array}$ & $\begin{array}{l}\text { Music did not significantly } \\
\text { reduce cortisol }\end{array}$ & $\begin{array}{l}\text { Additional research is needed } \\
\text { with larger sample size }\end{array}$ & $\begin{array}{l}\text { Music is more likely to be } \\
\text { effective in patients who have } \\
\text { similar characteristics to } \\
\text { cluster } 2 \text {. }\end{array}$ \\
\hline
\end{tabular}




\section{References}

1. Siu KC, Suh IH, Mukherjee M, Oleynikov D, Stergiou $\mathrm{N}$. The effect of music on robot-assisted laparoscopic surgical performance. Surg Innov 2010; 17, 306-311.

2. Thaut MH, Gardiner JC, Holmberg D, et al. Neurologic music therapy improves executive function and emotional adjustment in traumatic brain injury rehabilitation. Ann N Y Acad Sci 2009; 1169, 406-416.

3. Trompeo AC, Vidi Y, Locane MD, et al. Sleep disturbances in the critically ill patients: role of delirium and sedative agents. Minerva Anestesiol 2011; 77, 604-612.

4. Jackson P, Khan A. Delirium in critically ill patients. Crit Care Clin 2015; 31, 589-603.

5. Davis T, Jones P. Music therapy: decreasing anxiety in the ventilated patient: a review of the literature. Dimens Crit Care Nurs 2012; 31, 159-166.

6. Su CP, Lai HL, Chang ET, Yiin LM, Perng SJ, Chen PW. A randomized controlled trial of the effects of listening to non-commercial music on quality of nocturnal sleep and relaxation indices in patients in medical intensive care unit. J Adv Nurs 2013; 69, 1377 1389.

7. Chlan LL, Weinert CR, Heiderscheit A, et al. Effects of patient-directed music intervention on anxiety and sedative exposure in critically ill patients receiving mechanical ventilatory support: a randomized clinical trial. JAMA 2013; 309, 2335-2344.

8. Chlan L. Effectiveness of a music therapy intervention on relaxation and anxiety for patients receiving ventilatory assistance. Heart Lung 1998 May-Jun; 27(3):169-76.

9. Wong HL, Lopez-Nahas V, Molassiotis A. Effects of music therapy on anxiety in ventilator-dependent patients. Heart Lung 2001 Sep-Oct; 30(5):376-87.

10. Almerud S, Petersson K. Music therapy--a complementary treatment for mechanically ventilated intensive care patients. Intensive Crit Care Nurs 2003 Feb; 19(1):21-30.

11. Dijkstra BM, Gamel C, van der Bijl JJ, Bots ML, Kesecioglu J. The effects of music on physiological responses and sedation scores in sedated, mechanically ventilated patients. J Clin Nurs 2010 Apr; 19(78):1030-9.

12. White JM. Effects of relaxing music on cardiac autonomic balance and anxiety after acute myocardial infarction. Am J Crit Care 1999 Jul;8(4):220-30.

13. Barnason S, Zimmerman L, Nieveen J. The effects of music interventions on anxiety in the patient after coronary artery bypass grafting. Heart Lung 1995 MarApr; 24(2):124-32.

14. Elliott D. The effects of music and muscle relaxation on patient anxiety in a coronary care unit. Heart Lung 1994 Jan-Feb; 23(1):27-35.

15. Chlan LL, Engeland WC, Savik K. Does music influence stress in mechanically ventilated patients? Intensive Crit Care Nurs 2013 Jun; 29(3):121-7.
16. Chlan LL, Engeland WC, Anthony A, Guttormson J. Influence of music on the stress response in patients receiving mechanical ventilatory support: a pilot study. Am J Crit Care 2007 Mar; 16(2):141-5.

17. Chan MF, Chung YF, Chung SW, Lee OK. Investigating the physiological responses of patients listening to music in the intensive care unit. J Clin Nurs 2009; 18, 1250-1257.

18. Chi GC, Young A. Selection of music for inducing relaxation and alleviating pain: literature review. Holist Nurs Pract 2011; 25, 127-135.

\section{Details}

1. Submitted-11/18/2015

2. Accepted-9/23/2016

3. Reviewer-Steven Urban MD

4. Author affiliations- Phumpattra Chariyawong is a resident in Internal Medicine at Texas Tech University Health Sciences Center in Lubbock, TX. Samuel Copeland is a fellow in Pulmonary and Critical Care Medicine at TTUHSC in Lubbock, TX. Zachary Mulkey is a faculty member in Internal Medicine at TTUHSC in Lubbock, TX.

5. Corresponding author- Samuel Copeland at Samuel.copeland@ttuhsc.edu

6. Conflicts-none 